\title{
熊本水俣病認定審査会の1975年12月から1981年4月にかけての申請者に 対する1981年5月から1992年7月までの判断についての評価
}

\author{
宮 井 正 彌 \\ 岡山大学医学部衛生学教室

\begin{abstract}
An Appraisal of the Judgements of the Kumamoto Minamata Disease Certification Commission from May 1981 to July 1992 for Applicants from December 1975 to April 1981
\end{abstract} \\ Masaya MIYAI \\ Department of Hygiene \& Preventive Medicine, Okayama University Medical School, Okayama
}

\begin{abstract}
The differences of the diagnosis from December 1975 to April 1981 and from May 1981 to July 1992 of the Committee on Certification of Minamata Disease based on the medical records of 3,870 applicants who had been examined from December 1975 to April 1981 by the Committee were compared and analyzed from a statistical point of view.

Three hundred forty inhabitants from December 1975 to April 1981 and two hundred ninety eight inhabitants from May 1981 to July 1992, in total six hundred and thirty eight inhabitants, were certified to have Minamata disease by the Committee on Certification of Minamata Disease.

One hundred and eleven inhabitants who were judged likely to have Minamata disease by application of the present criteria presented by the Japanese Environmental Agency in 1977 were certified by the committee from May 1981 to July 1992, and one hundred and thirty three inhabitants who were judged not likely to have Minamata disease by application of the present criteria were certified from May 1981 to July 1992.

The author concluded that certification of the patients of Minamata disease by the Committee was inconsistent with the results of applying the present criteria to the data and that the prevalence of the symptoms of the inhabitants certified from December 1975 to April 1981 was inconsistent with that from May 1981 to July 1992.
\end{abstract}

Key words: Minamata disease（水俣病），nervous symptoms（神経症状）， certification（認定）

\section{緒 言}

水俣病は「アセトアルデヒド製造工程から副生さ れるメチル水銀が工場排水より持続的に流出し，こ れが食物連鎖を経由することにより，污染水域に生 息する魚介類に濃縮蓄積され，これら有毒魚介類を 反復多量摂取した人びとの間に発生をみたメチル水 銀中毒である」ッとされている。

その被害の規模が膨大であったにもかかわらず, 熊本水俣病に関しては今日に至るまで対象地区，年 度を特定して実施された調査報告例2-14)を除いて, 被

受付 1998年 2 月 12 日 受理 1999年 2 月22日

Reprint requests to: Masaya MIYAI,

Department of Hygiene \& Preventive Medicine, Okayama

University Medical School,

Shikata-cho, Okayama, 770, Japan

TEL: +81(729)92-8574 FAX: +81(729)23-3478
害があったと考えられる不知火海沿岸地区住民の悉 皆健康調査が継続して行われたことはなかった。 公式発見からすでに 40 年を過ぎた水俣病は，初期 においては急性典型例のみが強調された。同時にそ れらは水俣病であると認定されたが，その後はハン ター・ラッセル症候群を必ずしも満たさない症例が 認定作業の対象となり，水俣地域で発生した水俣病 は, 初期の病像から研究の親展に伴い, 変化が求め られてきた 15,20,21)。そして水俣病の認定をめぐって各地 で訴訟が起こされたが，一定の医学上の結論が出さ れないまま1995年に関西訴訟を除いて和解が成立し， 水俣病事件は過去の歴史になろうとしている。こう したなかで過去の健康障害に対する行政的な判断基 準とその意義を明かにしておくことは水俣病の医学 だけでなく今後の環境污染による健康影響の問題を 考える上でも重要であるとの報告がある ${ }^{15-22) 。 ま た ， ~}$ 
これまでの水俣病に関する裁判では従来の認定が不 適切であるとの裁判所の評価も下されており，認定 作業について一定の整理と評価をしておくことも重 要であると考えられる。

著者は1981年 4 月以前に熊本大学医学部の神経精 神科教室が診察し，1975年12月から1981年 4 月まで の認定審査会で審査を受けた症例 $(3,870$ 例) につい て健康障害の状況を記述すると共に, 現行の判断基 準を, 審査会の認定作業に用いられた38項目の症状 のなかの12項目の症状を用いて筆者らによる独自の 論理演算式を再構成し, この論理演算式を改めて本 症例に当てはめた結果と実際の認定審査会の判断の 結果とを比較することによって認定審査会の判断を 評価した ${ }^{23)}$ ここの1975年12月から1981年 4 月というの は熊本大学医学部神経精神科の教室員の一人が認定 審査会の委員であった時期である。

この分析に続いて本研究では1975年12月から 1981 年 4 月までの認定審査会で審査を受けた症例に対し て認定審査会が1981年 5 月以降どのような判断を下 したかを検討した。すなわち，認定審査会の1992年 7 月までの判断結果にもとづき今回用いた症例から 1981年 5 月以降に認定された例を抽出し，これらが どのような症状をもつ例であるかを検討し，さらに この症例に対して1975年12月から1981年 4 月までに 下された判断の内容を検討することによって審査会 の判断を評価した。

\section{研究の対象と方法}

\section{1. 研究の対象}

対象とした症例は，不知火海沿岸地域に住んでい るかあるいは住んでいたことがあり，水俣病への認 定申請を目的に熊本大学医学部神経精神科教室で診 察を受け，その診察の結果にもとづいて1975年12月 から1981年 4 月にかけて水俣病認定審査会において 審査を受けた症例 3,870 例である。ただしこのなかに はいくつかの項目において欠測值をもつ症例が存在 するため，欠測があった項目を用いた計算において はその欠測值をもつ症例の分だけ症例数が減少する。 神経精神科教室での診察は多人数で行なったので, そのばらつきをなくすために，教室員の一人がそれ らをまとめて，その資料を認定審査会に提出してい る。本研究ではこの審査会に提出した資料をもとに 38項目の症状とその他の項目にまとめ直した。この 1975年12月から1981年 4 月にかけては，申請者総数 は6,685名で，1959年 12 月に本人申請主義を義務づけ た認定制度が発足してから1995年 8 月までの実申請 者総数13,387名のほぼ半数に当たり，申請者数がピー クに達した時期である 24,25 。

今回用いた症例に対して1992年 7 月から 1997 年 9 月までに審査会が認定したのは 7 例だけであるから，
1992年 7 月の時点で保留あるいは不明とされていた 例は実質的に棄却と解釈される。

\section{2. 研究の方法}

3,870 人の症例について以下の項目を分析の対象と した。患者集団の生年, 診察時年齢, 家族内患者発 生の有無, 職業, 38項目の症状すなわち, 神経症, 発作性症状 ${ }^{26)}$, 言語障害, 舌運動障害, 病的反射低下, 同立進，粗大筋力低下，知覚障害，筋萎縮，静止時 振戦, 企図振戦, パーキンソン症状, アジアドコキ ネーシス, 指鼻テスト障害, 膝踵テスト障害, マン 現象陽性，ロンベルグ現象陽性，片足立ち障害，歩 行障害, つぎ足歩行障害, 動作緩慢, 視野狭窄, 視 野沈下, 追従性眼球運動障害, 衝動性眼球運動障害, 眼球振蕰, 白内障, 網膜色素変性, 純音聴力障害, 騷音性難聴, 聴力疲労, 語音聴力障害, OKP (OptKinetic-Pattern)陽性, 高血圧, 梅毒反応陽性, 澒椎異 常, 胸椎異常, 腰椎異常である。審査会における審 査は書類審査であり,これらの医学所見のみにもと づいて行なわれた。

まとめに記載された症状の程度を示す記号「 $3+」$

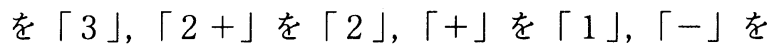

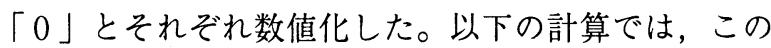
$\lceil 0 」 を 0$ とし，「1」，「2」，「3」および「4」を 1 とした。

知覚障害についてはその障害の部位によって，四 肢末端, 口周辺, 下半身, 半身, 全身, この 5 種類 に含まれないパターンを示したものを不規則とし， さらにこの 5 種類の部位を組み合わせた，四肢末 端十口周辺，四肢末端 + 下半身，四肢末端 + 半身， 四肢末端 + 全身，四肢末端 + 口周辺 + 下半身，四肢 末端 + 口周辺 + 半身，四肢末端 + 口周辺 + 全身， 口 周辺 + 半身, 口周辺十全身，の15種類のパターンに 分けた。

Table 1 Current Certification Criteria proposed by the Environment Agency in $1977^{27}$.

The certification requires that the patient has a history of methyl mercury exposure and satisfies at least one of the following conditions:

1. He/she shows both sensory disturbance and ataxia.

2. He/she shows both sensory disturbance and signs suggestive of cerebellar ataxia.

Concurrently, he/she has either abnormalities in equilibrium or bilateral concentric constriction in the visual field.

3. He/she shows both sensory disturbance and bilateral concentric constriction in the visual field.

Concurrently, he/she has signs suggestive of central lesions in the visual or auditory pathways.

4. He/she shows both sensory disturbance and signs suggestive of ataxia.

Also he/she has a constellation of other signs and symptoms. These neurologic deficits should be considered to be a result of methyl mercury exposure. 
1977年に環境庁から出された「後天性水俣病の判 断条件について」に基づく基準 ${ }^{27)}$ が現行の判断基準 であり, Table 1に示す通りである。自然言語で記載 されたこの判断基準における症状の組み合わせを, 審査会に提出され判断の資料とされた 38 項目の症状 のなかの12項目の症状を組み合せることによって Table 2に示すわれわれ独自の論理演算式を考案した。 すなわち, 判断条件に記載された「知覚障害」とし て審査会の判断に用いられた 38 項目の症状のうちの 「知覚障害」の特に「四肢末端の知覚障害」を, 同様 に「運動失調」として \{(アアジアドコキネーシス」 または「指鼻試験拙劣」) および（「膝踵試験拙劣」 または「歩行障害」)\}を，同様に「平衡機能障害」 として「OKP陽性」を, 同様に「両側性の求心性視 野狭窄」として「視野狭窄」を, 同様に「中枢性障
害を示す他の眼科又は耳鼻科の症候」として [(「追 従性眼球運動障害」または「衝動性眼球運動障害」) または「純音聴力障害」および（「聴力疲労」また は「語音聴力障害」)\}]をそれぞれ対応させた。さら に,「かつ」を and に,「あるいは」,「又は」を or に 対応させた。

このわれわれの論理演算式に本症例の症状を当て はめた。ただしこの判断条件には 4 項目の基準が記 載されているが, その基準 4 には抽象的な記述が含 まれこの論理演算式を作成することが困難であるた め除いた。

1992年 7 月までの認定審査会の判断結果にもとづ いて本症例から 1981年 5 月以降新たに認定された例 を抽出し，認定審査会の1975年12月から 1981年 4 月 までの判断と1981年 5 月から 1992年 7 月までの判断

Table 2 The Certification Criteria recomposed using signs and symptoms of the data shown in Table 4.

The Certification Criteria proposed by the Environment Agency were translated into the following statements:

$1 \mathrm{He} /$ she shows glove-and-stocking sensory disturbance.

Also, he/she shows either adiadochokinesis or abnormalities on the finger-nose test.

Furthermore, he/she shows either gait disturbance or abnormalities on the heel-shin test.

$2 \mathrm{He} /$ she shows glove-and-stocking sensory disturbance.

Also, he/she shows either adiadochokinesis, abnormalities on the finger-nose test, gait disturbance, or abnormalities on the heel-shin test.

Furthermore, he/she shows either abnormalities in the optokinetic pattern or bilateral concentric constriction in the visual field.

$3 \mathrm{He} /$ she shows glove-and-stocking sensory disturbance.

Also, he/she shows bilateral concentric constriction in the visual field.

Furthermore he/she shows signs suggestive of central lesions in either visual or auditory pathways.

The signs suggestive of central lesions in the visual pathway are defined as abnormalities of either pursuit or saccadic eye movements.

The signs suggestive of central lesions in the auditory pathway are defined as pure tone deafness and concomittent abnormalities in either the recruitment phenomenon or hearing impairment.

The Certification Criteria were translated into the following conditional statements for Boolean calculations.

1 SENSORY DISTURBANCE' $\geqq 1$ and ((ADIADOCHOKINESIA $\left.{ }^{2} \geqq 1\right)$ or $\left(\mathrm{FNT}^{3} \geqq 1\right)$ ) and $\left(\left(\mathrm{HST}^{4} \geqq 1\right)\right.$ or (GAIT DISTURBANCE $\left.{ }^{5} \geqq 1\right)$ )

2 SENSORY DISTURBANCE' $\geqq 1$ and ((ADIADOCHOKINESIA $\left.{ }^{2} \geqq 1\right)$ or $\left(\right.$ FNT $\left.^{3} \geqq 1\right)$ or $\left(\mathrm{HST}^{4} \geqq 1\right)$ or (GAIT DISTURBANCE $\left.{ }^{5} \geqq 1\right)$ ) and $\left(\left(\mathrm{OKP}^{6} \geqq 1\right)\right.$ or (VISUAL FIELD DEFECT $\left.{ }^{7} \geqq 1\right)$ )

3 SENSORY DISTURBANCE ${ }^{\prime} \geqq 1$ and VISUAL FIELD DEFECT ${ }^{7} \geqq 1$ and ((PURSUIT $\left.{ }^{8} \geqq 1\right)$ or $\left(\right.$ SACCADE $\left.\left.^{9} \geqq 1\right)\right)$ or $\left(\left(\right.\right.$ PURE TONE $\left.{ }^{10} \geqq 1\right)$ and ((RECRUITMENT" $\left.\geqq 1\right)$ or (HEARING IMPAIRMENT $\left.\left.{ }^{12} \geqq 1\right)\right)$ )

1 Glove-and-stocking type symmetric sensory disturbance

2 Adiadochokinesia

3 Abnormality in the finger-nose test

4 Abnormality in the heel-shin test

5 Gait disturbance

6 Abnormality in the optokinetic pattern

7 Concentric constriction of the visual field

8 Abnormality in pursuit eye movement

9 Abnormality in saccadic eye movement

10 Pure tone deafness

11 Positive recruitment phenomenon

12 Impairment in word discrimination 
Table 3 Contingency table showing the diagnosis by the committee and that based on our conditional statements.

\begin{tabular}{|c|c|c|c|c|c|c|c|c|c|c|}
\hline \multicolumn{11}{|c|}{ Conditional statements } \\
\hline & \multicolumn{4}{|c|}{ Satisfied } & \multicolumn{3}{|c|}{ Not satisfied } & \multicolumn{3}{|c|}{ Total } \\
\hline & Certified & $205^{*}$ & $(+111)$ & $316 \#$ & $74^{*}$ & $(+133)$ & $207 \#$ & $279^{*}$ & $(+244)$ & $523 \#$ \\
\hline \multirow[t]{4}{*}{ Committee } & Denied & $126^{*}$ & $(-3)$ & $123 \#$ & $1457^{*}$ & $(-21)$ & $1436 \#$ & $1583^{*}$ & $(-24)$ & $1559 \#$ \\
\hline & Deferred & $611^{*}$ & $(-107)$ & $504 \#$ & $889^{*}$ & $(-103)$ & $786 \#$ & $1500^{*}$ & $(-210)$ & $1290 \#$ \\
\hline & Suspected & $2^{*}$ & $(-1)$ & $1 \#$ & $31^{*}$ & $(-9)$ & $22 \#$ & $33^{*}$ & $(-10)$ & 23\# \\
\hline & Total & \multicolumn{3}{|c|}{944} & \multicolumn{3}{|c|}{2451} & \multicolumn{3}{|c|}{3395} \\
\hline
\end{tabular}

*Data dased on the diagnosis of the committee from December 1975 to April 1981

\#Data based on the diagnosis of the committee from December 1975 to July 1922.

Numbers in parentheses show the variation in the number of patients at each cell by the diagnosis of the committee from May 1981 to July 1992 mpared with that from December 1975 to April 1981.

Table 4 Number and prevalence(\%) of the patients group certified by the committee from December 1975 to April 1981 and from May 1981 to July 1992 respectively.

\begin{tabular}{|c|c|c|c|c|c|}
\hline No.Signs and symptoms & \multicolumn{2}{|c|}{$\begin{array}{c}\text { Dec.'75-Apr.' } 81 \\
(\mathrm{n}=279) \\
\mathrm{n}(\%)\end{array}$} & \multicolumn{2}{|c|}{$\begin{array}{c}\text { May '81-July'92 } \\
(\mathrm{n}=244) \\
\mathrm{n}(\%)\end{array}$} & \multirow{2}{*}{$\begin{array}{c}\begin{array}{c}\text { Chi-square } \\
\text { test }\end{array} \\
0.44\end{array}$} \\
\hline 1 Neurosis & 45 & $(16.1)$ & 30 & $(12.3)$ & \\
\hline 2 Paroxysmal symptom & 54 & $(19.4)$ & 63 & $(25.8)$ & 0.73 \\
\hline 3 Dysarthria & 69 & $(24.7)$ & 66 & $(27.0)$ & 0.08 \\
\hline 4 Abnormal lingual movement & 6 & $(2.2)$ & 3 & $(1.2)$ & 0.28 \\
\hline 5 Hyporeflexia & 19 & $(6.8)$ & 13 & $(5.3)$ & 0.17 \\
\hline 6 Hyperreflexia & 71 & $(25.4)$ & 38 & $(15.6)$ & 1.94 \\
\hline 7 Muscle weakness & 99 & $(35.5)$ & 73 & $(29.9)$ & 0.36 \\
\hline 8 Sensory disturbance & $248 \#$ & $(88.9 \#)$ & $187 \#$ & $(76.6 \#)$ & 0.50 \\
\hline 9 Muscular atrophy & 12 & $(4.3)$ & 6 & $(2.5)$ & 0.46 \\
\hline 10 Rest tremor & 106 & $(38.0)$ & 76 & $(31.1)$ & 0.51 \\
\hline 11 Intension tremor & 63 & $(22.6)$ & 24 & $(9.8)$ & $4.36^{*}$ \\
\hline 12 Parkinsonism & 9 & ( 3.2$)$ & 3 & $(1.2)$ & 0.88 \\
\hline 13 Adiadochokinesia & 192 & $(68.8)$ & 129 & $(52.9)$ & 1.29 \\
\hline 14 Abnormal finger-nose test & 154 & $(55.2)$ & 94 & $(38.5)$ & 2.03 \\
\hline 15 Abnormal heel-shin test & 168 & $(60.2)$ & 110 & $(45.1)$ & 1.42 \\
\hline 16 Abnormal Mann's test & 138 & $(49.5)$ & 124 & $(50.8)$ & 0.01 \\
\hline 17 Positive Romberg's sign & 61 & $(21.9)$ & 34 & $(13.9)$ & 1.51 \\
\hline 18 Inability to stand on one leg & 103 & $(36.9)$ & 43 & (17.6) & $5.40^{*}$ \\
\hline 19 Gait disturbance & 55 & $(19.7)$ & 26 & $(10.7)$ & 2.31 \\
\hline 20 Inability of tandem gait & 175 & $(62.7)$ & 132 & $(54.1)$ & 0.40 \\
\hline 21 Bradykinesia & 140 & $(50.2)$ & 71 & $(29.1)$ & $4.04^{*}$ \\
\hline 22 Concentric defect of the visual field & 106 & $(38.0)$ & 38 & (15.6) & $7.44^{* *}$ \\
\hline 23 Depression of visual field & 109 & $(39.1)$ & 41 & $(16.8)$ & $7.00^{* *}$ \\
\hline 24 Abnormal pursuit eye movement & 62 & $(22.2)$ & 40 & $(16.4)$ & 0.73 \\
\hline 25 Abnormal saccadic eye movement & 13 & ( 4.7$)$ & 9 & $(3.7)$ & 0.11 \\
\hline 26 Nystagmus & 9 & $(3.2)$ & 6 & $(2.5)$ & 0.08 \\
\hline 27 Cataract & 6 & $(2.2)$ & 1 & $(0.4)$ & 1.23 \\
\hline 28 Retinal pigmentary degeneration & 2 & $(0.7)$ & 3 & $(1.2)$ & 0.13 \\
\hline 29 Pure tone deafness & 185 & $(66.3)$ & 122 & $(50.0)$ & 1.44 \\
\hline 30 Noise-induced deafness & 20 & $(7.2)$ & 14 & $(5.7)$ & 0.16 \\
\hline 31 Positive recruitment phenomenon & 114 & $(40.9)$ & 61 & $(25.0)$ & 2.89 \\
\hline 32 Impairment in word discrimination & 99 & $(35.5)$ & 57 & $(23.4)$ & 1.92 \\
\hline 33 Abnormal optokinetic pattern & 167 & $(59.9)$ & 89 & $(36.5)$ & 3.85 \\
\hline 34 Hypertension & 102 & $(36.6)$ & 86 & $(35.2)$ & 0.02 \\
\hline 35 Positive serologic test for syphilis & 22 & $(7.9)$ & 7 & $(2.9)$ & 2.19 \\
\hline 36 Abnormal cervical spine & 50 & $(17.9)$ & 26 & $(10.7)$ & $14.64^{* *}$ \\
\hline 37 Abnormal thoracic spine & 5 & $(1.8)$ & 4 & $(1.6)$ & 1.01 \\
\hline 38 Abnormal lumbar spine & 28 & $(10.0)$ & 21 & $(8.6)$ & 0.09 \\
\hline
\end{tabular}

\# This number includes only the patients who showed symmetric glove-and-stocking sensory involvement.

* Significant at $1 \%$ level. ${ }^{* *}$ Singnificant at $5 \%$ level. 
Table 5 Prevalence (\%) of sensory disturbances in the patient group certified by the committee from December 1975 to April 1981 and from May 1981 to July 1992 by respectively.

\begin{tabular}{|c|c|c|}
\hline Involvement & $\begin{array}{c}\text { Dec.'75-Apr.' } 81 \\
(n=279)\end{array}$ & $\begin{array}{c}\text { May'81-July'92 } \\
(n=244)\end{array}$ \\
\hline 1 Symmetric glove-and-stocking sensory disturbance & 62.0 & 57.8 \\
\hline 2 Perioral & 0.4 & 0.0 \\
\hline 3 Unilateral leg & 0.0 & 0.4 \\
\hline 4 Unilateral arm and leg & 1.4 & 2.0 \\
\hline 5 Generalized & 4.3 & 9.8 \\
\hline 6 Irregular & 1.1 & 0.8 \\
\hline 7 Symmetric glove-and-stocking and perioral & 17.9 & 9.8 \\
\hline 8 Symmetric glove-and-stocking and unilateral leg & 2.5 & 2.0 \\
\hline 9 Symmetric glove-and-stocking and unilateral arm and leg & 2.9 & 3.7 \\
\hline 10 Symmetric glove-and-stocking and generalized & 2.9 & 2.9 \\
\hline 11 Perioral and unilateral arm and leg & 0.0 & 0.0 \\
\hline 12 Symmetric glove-and-stocking, perioral, and unilateral leg & 0.7 & 0.4 \\
\hline 13 Symmetric glove-and-stocking, perioral, and unilateral arm and leg & 0.4 & 0.0 \\
\hline 14 Symmetric glove-and-stocking, perioral, and generalized & 1.1 & 0.4 \\
\hline 15 Perioral and generalized & 0.0 & 0.0 \\
\hline 16 No disturbance & 2.5 & 9.8 \\
\hline
\end{tabular}

とを比較した。

\section{結 果}

\section{1．症例集団の性質}

3,870 例の症例の生年の分布は工場が1908年にカー バイドの製造を開始したころから漁業被害が発生し た1925年さらにアセトアルデヒドの製造を開始した 1932年にかけてが多く，大部分はチッソ付属病院細 川一院長が，「原因不明の中枢性神経疾患が多発して いる」と水俣保健所に報告した1956年以前である。

\section{2. 認定審査会の判断}

1975年12月から1981年 4 月までに本症例に対して 認定審査会が水俣病であると認定した例は340例（認 定の割合は8.8\%）であったが，1981年 5 月から 1992 年 7 月までに認定された例は 298 例であり，合計 638 例となり，認定の割合は $16.4 \%$ であった。

\section{3.筆者らの論理演算式を用いた評価}

本症例に対して1975年12月から1981年 4 月までの 認定審査会の判断と筆者らの論理演算式へ当てはめ た結果との関連を示す分割表はすでに示したが23)，こ の分割表にさらに1981年 5 月から 1992年 7 月までの 認定審査会の判断を加えた結果をTable 3に示す。 3,870 例のデータのうち久測値があったために計算に 有効な例数は3,395例となった。筆者らの論理演算式 を満たした 944 例のうち1975年12月から 1981年 4 月ま での認定審査会で認定されたのは205例であり，1981 年 5 月から 1992年 7 月までに認定されたのは111例で あった。筆者らの論理演算式を満たさなかった 2451 例のうち1975年12月から1981年 4 月までに認定され たのは74例であり，1981年 5 月から 1992年 7 月まで
は133例であった。

筆者らの論理演算式を満たすが 1975 年 12 月から 1981年 4 月までの審査会では認定されず，1981年 5 月から1992年 7 月までに認定された111例の内訳は， 審査会で棄却とされていたのが 3 例，保留とされて いたのが107例，不明とされていたのが 1 例であった。 筆者らの論理演算式を満たさず1981年 5 月から 1992 年 7 月までに審査会で認定と判断された133例の内訳 は，1975年12月から1981年 4 月までに審査会で棄却 と判断されていたのが 21 例，保留と判断されていた のが103例，不明と判断されていたのが 9 例であった。 この133例について検討した。

棄却とされていた 21 例については，四肢末端の知 覚障害をもたないのが 4 例，運動失調に関する症状 をもたないのが 3 例，視聴覚に関する症状をもたな いのが 3 例，運動失調ならびに視聴覚関係の症状を もたないのが11例であった。保留とされていた103例 については，四肢末端の知覚障害をもたないのが 44 例，運動失調に関する症状をもたないのが17例，視 聴覚に関する症状をもたないのが14例，運動失調な らびに視聴覚関係の症状をもたないのが25例，四肢 末端の知覚障害, 運動失調, 視聴覚の障害をもつが 論理演算式を満たすまでには至らなかったのが 3 例 であった。不明とされていた 9 例については，視覚 関係の症状をもたない 1 例を除いて他の 8 例はすべ て症状をもたなかった。

1975年12月から 1981年 4 月までに認定審査会で認 定された 279 例と 1981 年 5 月から1992年 7 月までに認 定された 244 例とを比較するため, 38項目の症状の有 症の割合および15種類の知覚障害のパターンの出現 の割合を比較検討した（Table 4, Table 5)。38項目の 症状については1975年12月から1981年 4 月までに認 定された群に較べ1981年 5 月から 1992年 7 月までに 
認定された群は企図振戦, 片足立ち, 動作緩慢, 視 野狭窄, 視野沈下, 頚椎障害の 6 項目の症状の有症 の割合が有意に低く，それ以外の症状においても概 ね低かった。知覚障害については全身の出現の割合 が高く, 四肢末端十口周囲が低いという特徽を示し た。

本症例に対して，1992年 7 月から1997年 9 月まで に審査会が認定したのは 7 例だけであるから，1992 年 7 月で保留あるいは不明とされていた例は実質的 に裹却と解釈される。認定された 523 例とそれ以外の 2,872例とを比較するため, それぞれの群における38 項目の症状の有症の割合および15種類の知覚障害の パターンの出現の割合を検討した（Table 6, Table 7)。
38項目の症状については認定者群では非認定者群に 較べて, 病的反射元進, 企図振戦, アジアドコキネ 一シス, 指鼻試験, 膝踵試験, 片足立ち, 歩行障害, つぎ足歩行, 動作緩慢, 視野狭窄, 視野沈下, 聴力 疲労, 語音聴力障害, OKP陽性の14項目の症状にお いて有症の割合が有意に高かった。知覚障害につい ては, 認定者群では非認定者群に較べ四肢末端の出 現の割合は変わらないが, 四肢末端十口周囲は高い, という特徴を示した。

筆者らの論理演算式を満たし認定審査会でも認定 とされた316例 (A群), 論理演算式を満たすが認定審 査会で認定とされなかった628例 (B群), 論理演算式 を満たさないが認定審査会では認定とされた207例

Table 6 Number and prevalence $(\%)$ of the patient certified by the committee and others.

\begin{tabular}{|c|c|c|c|c|c|}
\hline \multirow[t]{2}{*}{ No. Signs and symptoms } & \multicolumn{2}{|c|}{$\begin{array}{l}\text { Certified } \\
(\mathrm{n}=523)\end{array}$} & \multicolumn{2}{|c|}{$\begin{array}{l}\text { The others } \\
(\mathrm{n}=2872)\end{array}$} & \multirow[t]{2}{*}{$\begin{array}{c}\text { Chi-square } \\
\text { test }\end{array}$} \\
\hline & $\mathrm{n}$ & (\%) & $\mathrm{n}$ & (\%) & \\
\hline 1 Neurosis & 75 & $(14.3)$ & 261 & $(9.1)$ & 1.03 \\
\hline 2 Paroxysmal symptom & 117 & $(22.4)$ & 586 & $(20.4)$ & 0.07 \\
\hline 3 Dysarthria & 135 & $(25.8)$ & 451 & $(15.7)$ & 2.03 \\
\hline 4 Abnormal lingual movement & 9 & $(1.7)$ & 26 & $(0.9)$ & 0.24 \\
\hline 5 Hyporeflexia & 32 & $(6.1)$ & 106 & $(3.7)$ & 0.56 \\
\hline 6 Hyperreflexia & 109 & $(20.8)$ & 250 & (8.7) & $4.33^{*}$ \\
\hline 7 Muscle weakness & 172 & (32.9) & 657 & $(22.9)$ & 1.40 \\
\hline 8 Sensory disturbance & 435\# & $(83.2 \#)$ & $2056 \#$ & (71.6\#) & 0.49 \\
\hline 9 Muscular atrophy & 18 & $(3.4)$ & 66 & $(2.3)$ & 0.20 \\
\hline 10 Rest tremor & 182 & $(34.8)$ & 572 & $(19.9)$ & 3.19 \\
\hline 11 Intension tremor & 87 & $(16.6)$ & 141 & $(4.9)$ & $5.76^{*}$ \\
\hline 12 Parkinsonism & 12 & $(2.3)$ & 37 & $(1.3)$ & 0.27 \\
\hline 13 Adiadochokinesia & 321 & $(61.4)$ & 821 & $(28.6)$ & $8.35^{* *}$ \\
\hline 14 Abnormal finger-nose test & 248 & $(47.4)$ & 520 & $(18.1)$ & $9.99^{* *}$ \\
\hline 15 Abnormal heel-shin test & 278 & $(53.2)$ & 638 & $(22.2)$ & $9.37^{* *}$ \\
\hline 16 Abnormal Mann's test & 262 & $(50.1)$ & 942 & $(32.8)$ & 2.56 \\
\hline 17 Positive Romberg's sign & 95 & $(18.2)$ & 264 & $(9.2)$ & 2.60 \\
\hline 18 Inability to stand on one leg & 146 & $(27.9)$ & 313 & $(10.9)$ & $6.27^{*}$ \\
\hline 19 Gait disturbance & 81 & $(15.5)$ & 152 & $(5.3)$ & $4.54^{*}$ \\
\hline 20 Inability of tandem gait & 307 & $(58.7)$ & 916 & $(31.9)$ & $5.50^{*}$ \\
\hline 21 Bradykinesia & 211 & $(40.3)$ & 514 & (17.9) & $6.72^{* *}$ \\
\hline 22 Concentric defect of the visual field & 144 & $(27.5)$ & 178 & $(6.2)$ & $11.61^{* *}$ \\
\hline 23 Depression of visual field & 150 & $(28.7)$ & 261 & $(9.1)$ & $8.60^{* *}$ \\
\hline 24 Abnormal pursuit eye movement & 102 & $(19.5)$ & 356 & $(12.4)$ & 1.36 \\
\hline 25 Abnormal saccadic eye movement & 22 & $(4.2)$ & 32 & $(1.1)$ & 1.76 \\
\hline 26 Nystagmus & 15 & (2.9) & 60 & $(2.1)$ & 0.12 \\
\hline 27 Cataract & 7 & (1.3) & 26 & $(0.9)$ & 0.07 \\
\hline 28 Retinal pigmentary degeneration & 5 & $(1.0)$ & 37 & $(1.3)$ & 0.03 \\
\hline 29 Pure tone deafness & 307 & $(58.7)$ & 882 & $(30.7)$ & $6.11^{*}$ \\
\hline 30 Noise-induced deafness & 34 & $(6.5)$ & 169 & $(5.9)$ & 0.02 \\
\hline 31 Positive recruitment phenomenon & 175 & $(33.5)$ & 407 & $(14.2)$ & $6.34^{*}$ \\
\hline 32 Impairment in word discrimination & 156 & $(29.8)$ & 264 & $(9.2)$ & $9.17^{* *}$ \\
\hline 33 Abnormal optokinetic pattern & 256 & $(48.9)$ & 758 & $(26.4)$ & $4.91^{*}$ \\
\hline 34 Hypertension & 188 & $(35.9)$ & 856 & $(29.8)$ & 0.42 \\
\hline 35 Positive serologic test for syphilis & 29 & $(5.5)$ & 57 & $(2.0)$ & 1.57 \\
\hline 36 Abnormal cervical spine & 76 & $(14.5)$ & 192 & $(6.7)$ & 2.59 \\
\hline 37 Abnormal thoracic spin & 9 & $(1.7)$ & 35 & $(1.2)$ & 0.08 \\
\hline 38 Abnormal lumbar spine & 49 & (9.4) & 126 & $(4.4)$ & 1.69 \\
\hline
\end{tabular}

\# This number includes only the patients who showed symmetric glove-and-stocking sensory involvement.

${ }^{*}$ Significant at $1 \%$ level. ${ }^{* *}$ Significant at $5 \%$ level. 
Table 7 Prevalence (\%) of sensory disturbances in the patient group certified by the committee and others.

\begin{tabular}{|c|c|c|}
\hline No. $\quad$ Involvement & $\begin{array}{l}\text { Certified } \\
(\mathrm{n}=523)\end{array}$ & $\begin{array}{l}\text { The others } \\
(\mathrm{n}=2872)\end{array}$ \\
\hline 1 Symmetric glove-and-stocking sensory disturbance & 60.0 & 57.4 \\
\hline 2 Perioral & 0.2 & 0.1 \\
\hline 3 Unilateral leg & 0.2 & 0.7 \\
\hline 4 Unilateral arm and leg & 1.7 & 3.3 \\
\hline 5 Generalized & 6.9 & 4.2 \\
\hline 6 Irregular & 1.0 & 7.0 \\
\hline 7 Symmetric glove-and-stocking and perioral & 14.1 & 4.4 \\
\hline 8 Symmetric glove-and-stocking and unilateral leg & 2.3 & 2.4 \\
\hline 9 Symmetric glove-and-stocking and unilateral arm and leg & 3.3 & 5.4 \\
\hline 10 Symmetric glove-and-stocking and generalized & 2.9 & 1.8 \\
\hline 11 Perioral and unilateral arm and leg & 0.0 & 0.0 \\
\hline 12 Symmetric glove-and-stocking, perioral, and unilateral leg & 0.6 & 0.2 \\
\hline 13 Symmetric glove-and-stocking, perioral, and unilateral arm and leg & 0.2 & 0.0 \\
\hline 14 Symmetric glove-and-stocking, perioral, and generalized & 0.8 & 0.1 \\
\hline 15 Perioral and generalized & 0.0 & 0.0 \\
\hline 16 No disturbance & 5.9 & 13.0 \\
\hline
\end{tabular}

(C群)，論理演算式を満たさないで認定審査会でも認 定とされなかった2,244例（D群）を比較するため， それぞれについて38項目の症状の有症の割合および 15種類の知覚障害のパターンの出現の割合を検討し た (Table 8, Table 9)。

38項目の症状の有症の割合は全体的にはA群，B群， C群, D群に従って低下し, 視野狭窄, 視野沈下, 純 音聴力障害, 聴力疲労, 語音聴力障害についてはB群 よりC群の方が高かった。知覚障害の出現の割合につ いてはA，B群はC，D群に較べて四肢末端, 四肢末 端十口周囲が高く、またC群はD群に較べ四肢末端が 低く，全身が高いという特徴を示した。

\section{考 察}

本研究で用いた症例の症状は熊本大学医学部神経 精神科教室の複数の医師の診察によるものである。 新潟大学の複数の医師との合同の診察を通して両大 学の間では知覚障害, 視野狭窄, 運動失調での臨床 所見で若干の相違はみられたが大差はないことが確 かめられ，この熊本大学医学部精神神経科教室の複 数の医師による診断のばらつきはこれよりさらに少 ないと考えられる28300。

1975年 12 月から 1981 年 4 月までに本症例に対して 認定審査会が水俣病であると認定した例は 340 例で認 定の割合は $8.8 \%$ であったが, 1981年 5 月から 1992年 7 月までは298例であり, 合計638例となり, 認定の 割合は $16.4 \%$ \%゙った。このようにいったん保留や棄 却とされた例が，一定期間後に認定され，その認定 者数はそれ以前のほほ 2 倍となっていることを明ら かにした。

審査会で認定と判断されてかつ筆者らが考案した 論理演算式を満たさなかった例について検討したと
ころ, 審査会においては現行の判断基準を満たさな い症例であっても認定している状況が認められる。 これは論理演算式としてデータの当てはめをしなか った判断基準の 4 に該当した症例を審査会において 認定と判断したとも考えられる。

1975年12月から 1981年 4 月までの認定審査会の判 断では筆者らの論理演算式を満たした例で審査会の 判断に多いのは保留例であるから，これらの保留例 を認定に移行すれば筆者らの論理演算式を満たした 数にほほ一致すると指摘したが23，1981年 5 月から 1992年 7 月までの判断では，この保留例から107例が 認定されている。しかし筆者らの論理演算式を満た さない例からも133例が認定されているが，このこと は現行の判断基準を満たさない例であっても認定し たことを示唆している。

1975年12月から 1981年 4 月までに認定審査会で認 定された279例と1981年 5 月から 1992 年 7 月までに認 定された244例とを比較すると，38項目の症状につい ては，前者に較べ後者は企図振戦，片足立ち，動作 緩慢, 視野狭窄, 視野沈下, 脊椎障害の 6 項目の症 状の有症の割合が有意に低く，それ以外の症状にお いても低かった。また知覚障害については全身の出 現の割合が高く，四肢末端十口周囲が低いという特 徵を示した。これは申請者の症状が悪化したからと も考えられるが，244例のうち，210例は保留とされ た例からであり，再申請をしていないので，判断に 用いられた症状は同一であることから，認定審査会 は時間の経過に従って症状のとりかたを緩くしたと 考えられ，判断基準の一貫した適用がなされていな かったことを示唆している。

1992年 7 月までの認定審査会の判断は本症例に対 して最終的なものと考えられるが，認定者群とそれ 以外の群とを比較すると 38 項目の症状の有症の割合 
Table 8 Prevalence (\%) of 38 signs and symptoms in the patient group (A) certified by the committee and satisfied by our conditional statements, group (B) denied by the committee and satisfied by our conditional statements, group (C) certified by the committee and not satisfied by our conditional statements, group (D) not certified by the committee and not satisfied by our conditional statements.

\begin{tabular}{|c|c|c|c|c|}
\hline No. Signs and symptoms & $\begin{array}{c}\mathrm{A} \\
(\mathrm{n}=316)\end{array}$ & $\begin{array}{c}\mathrm{B} \\
(\mathrm{n}=628)\end{array}$ & $\begin{array}{c}\mathrm{C} \\
(\mathrm{n}=207)\end{array}$ & $\begin{array}{c}D \\
(n=2244)\end{array}$ \\
\hline 1 Neurosis & 17.4 & 16.6 & 9.7 & 7.0 \\
\hline 2 Paroxysmal symptom & 23.1 & 25.2 & 21.3 & 19.1 \\
\hline 3 Dysarthria & 26.9 & 28.2 & 24.2 & 12.3 \\
\hline 4 Abnormal lingual movement & 1.6 & 1.1 & 1.9 & 0.8 \\
\hline 5 Hyporeflexia & 8.2 & 6.1 & 2.9 & 3.1 \\
\hline 6 Hyperreflexia & 25.6 & 13.1 & 13.5 & 7.5 \\
\hline 7 Muscle weakness & 36.7 & 35.5 & 27.1 & 19.4 \\
\hline 8 Sensory disturbance & 100.0\# & $100.0 \#$ & $57.5 \#$ & $63.6 \#$ \\
\hline 9 Muscular atrophy & 3.5 & 3.0 & 3.4 & 2.1 \\
\hline 10 Rest tremor & 38.9 & 33.3 & 28.5 & 16.2 \\
\hline 11 Intention tremor & 21.8 & 10.4 & 8.7 & 3.4 \\
\hline 12 Parkinsonism & 2.5 & 1.6 & 1.9 & 1.2 \\
\hline 13 Adiadochokinesia & 80.7 & 77.9 & 31.9 & 14.8 \\
\hline 14 Abnormal finger-nose test & 64.9 & 54.9 & 20.8 & 7.8 \\
\hline 15 Abnormal heel-shin test & 73.3 & 70.7 & 19.3 & 8.7 \\
\hline 16 Abnormal Mann's test & 57.0 & 61.8 & 39.6 & 24.6 \\
\hline 17 Positive Romberg's sign & 21.5 & 18.9 & 13.0 & 6.5 \\
\hline 18 Inability to stand on one leg & 35.1 & 25.5 & 16.9 & 6.8 \\
\hline 19 Gait disturbance & 20.6 & 15.8 & 7.7 & 2.3 \\
\hline 20 Inablity of tandem gait & 69.6 & 61.5 & 42.0 & 23.7 \\
\hline 21 Bradykinesia & 47.8 & 35.7 & 29.0 & 13.0 \\
\hline 22 Concentric constriction of visual field & 32.3 & 14.0 & 20.3 & 4.0 \\
\hline 23 Depression of visual field & 32.6 & 15.3 & 22.7 & 7.4 \\
\hline 24 Abnormal pursuit eye movement & 20.6 & 17.4 & 17.9 & 11.0 \\
\hline 25 Abnormal saccadic eye movement & 4.7 & 1.9 & 3.4 & 0.9 \\
\hline 26 Nystagmus & 1.9 & 2.7 & 4.3 & 1.9 \\
\hline 27 Cataract & 1.3 & 1.6 & 1.4 & 0.7 \\
\hline 28 Retinal pigmentary degeneration & 0.6 & 1.9 & 1.4 & 1.1 \\
\hline 29 Pure tone deafness & 67.7 & 40.9 & 44.9 & 27.8 \\
\hline 30 Noise-induced deafness & 6.3 & 7.8 & 6.8 & 5.3 \\
\hline 31 Positive recruitment phenomenon & 37.7 & 20.9 & 27.1 & 12.3 \\
\hline 32 Impairment in word discrimination & 35.8 & 15.1 & 20.8 & 7.5 \\
\hline 33 Abnormal optokinetic pattern & 57.9 & 52.4 & 35.3 & 19.2 \\
\hline 34 Hypertension & 37.0 & 36.6 & 34.3 & 27.9 \\
\hline 35 Positive serologic test for syphilis & 6.3 & 2.7 & 4.3 & 1.8 \\
\hline 36 Abnormal cervical spine & 18.0 & 9.7 & 9.2 & 5.8 \\
\hline 37 Abnormal thoracic spine & 2.5 & 1.4 & 0.5 & 1.2 \\
\hline 38 Abnormal lumbar spine & 10.8 & 6.1 & 7.2 & 4.0 \\
\hline
\end{tabular}

\# This number includes only the patients who showed symmetric glove-and-stocking sensory involvement.

については前者は15項目の症状で有意に高かった。 知覚障害については四肢末端の出現の割合は変わら ないが，四肢末端十口周囲は高いという特徵を示し た。口周囲がメチル水銀中毒に比較的特異的だと認 識されているからではないかと推測される。

次に，筆者らの論理演算式を満たし認定審査会で も認定とされた 316 例（A群），この論理演算式を満た すが認定審査会で認定とされなかった628例（B群）, この論理演算式を満たさないが認定審査会では認定 とされた207例 (C群), この論理演算式を満たさない で認定審査会でも認定とされなかった 2,244 例（D群）
それぞれについて38項目の症状の有症の割合および 15種類の知覚障害のパターンの出現の割合を検討し た。38種類の症状の有症の割合は, 全体的にはA群, B群，C群，D群の順に従って低い。つまりC群よりも B群における症状に有症の割合が高いものが多いとい うことは, 認定審査会で認定されかつ筆者らの論理 演算式を満たさない群よりも認定審査会で認定され ないでこの論理演算式を満たす群のほうが症状を多 く持つということを示唆している。それほど変化が ない症状もあるが, これらの症状は認定審査会の判 断には寄与しなかったということであろう。視野狭 
Tabie 9 Prevalence (\%) of sensory disturbances in the patients group (A) certified by the committee and satisfied by our conditional statements, group (B) denied by the committee and satisfied by our conditional statements, group (C) certified by the committee and satisfied by our conditional statements, group (D) denied by the committee and not satisfied by our conditional statement.

\begin{tabular}{|c|c|c|c|c|c|}
\hline No. & Involvement & $\begin{array}{c}A \\
(n=316)\end{array}$ & $\begin{array}{c}B \\
(n=628)\end{array}$ & $\begin{array}{c}C \\
(n=207)\end{array}$ & $\begin{array}{c}\mathrm{D} \\
(\mathrm{n}=2244)\end{array}$ \\
\hline 1 & Symmetric glove-and-stocking sensory disturbance & 70.3 & 72.3 & 44.4 & 53.3 \\
\hline 2 & Perioral & 0.0 & 0.0 & 0.5 & 0.1 \\
\hline 3 & Unilateral leg & 0.0 & 0.0 & 0.5 & 0.8 \\
\hline 4 & Unilateral arm and leg & 0.0 & 0.0 & 4.3 & 4.2 \\
\hline 5 & Generalized & 0.0 & 0.0 & 17.4 & 5.4 \\
\hline 6 & Irregular & 0.0 & 0.0 & 2.4 & 9.0 \\
\hline 7 & Symmetric glove-and-stocking and perioral & 19.9 & 10.2 & 5.3 & 2.7 \\
\hline 8 & Symmetric glove-and-stocking and unilateral leg & 2.2 & 4.0 & 2.4 & 1.9 \\
\hline 9 & Symmetric glove-and-stocking and unilateral arm and leg & 3.8 & 9.1 & 2.4 & 4.4 \\
\hline 10 & Symmetric glove-and-stocking and generalized & 208 & 3.7 & 2.9 & 1.3 \\
\hline 11 & Perioral and unilateral arm and leg & 0.0 & 0.0 & 0.0 & 0.0 \\
\hline 12 & Symmetric glove-and-stocking, perioral, and unilateral leg & 0.9 & 0.8 & 0.0 & 0.0 \\
\hline 13 & Symmetric glove-and-stocking, perioral, and unilateral arm and leg & 0.0 & 0.0 & 0.5 & 0.0 \\
\hline 14 & Symmetric glove-and-stocking, perioral, and generalized & 0.0 & 0.0 & 1.9 & 0.1 \\
\hline 15 & Perioral and generalized & 0.0 & 0.0 & 0.0 & 0.0 \\
\hline 16 & No disturbance & 0.0 & 0.0 & 15.0 & 16.6 \\
\hline
\end{tabular}

窄, 視野沈下, 純音聴力障害, 聴力疲労, 語音聴力 障害ではB群よりC群の方が高く，認定審査会の判断 の材料とされたことを示唆した。知覚障害について は筆者らの論理演算式は満たさないが認定審査会で は認定とされた群において四肢末端が低く，不規則， なしが高く，このことは上述の103例の検討で44例が 四肢末端の症状をもたないということとも一致する。

本研究における論理演算式は, 熊本大学医学部精 神神経科の教室員であり同時に熊本水俣病認定審査 会の委員の一人であった医師の意見を参考にして作 成した。当医師は長年にわたって何千人もの患者を 診察した経験があり，同時に審査会委員として神経 内科の専門医と打ち合わせを繰り返してきた経歴が ある。また論理式自体は症例に当てはめた結果を見 て修正をしたわけではなく，1回で決定したもので ある。さらに,この論理論理式に関して別の神経内 科の専門医が独自の論理演算式を構成し本症例に当 てはめたところ, 本研究に示した結果とほとんど差 はなかった。

本研究におけるバイアスとして昭和 52 年に環境庁 が出した判断条件が考えられるが，環境庁，判断条 件を審議した委員，審査会委員ともに，この判断基 準によって実際の審査内容が変化しなかったと表明 していることから，これはそれほど影響を与えてい ないと考えられる。

審査会資料は門外不出の県のデータとされている が，本研究には個人名は出されていないので特に問 題はなく，むしろ水俣病の認定が大きな社会問題と なっていることから，できるだけ早急にこの問題に 対して 1 つの客観的な評価の材料を提出することの 方が重要と考えた。
本研究では，認定された群とそうでなかった群に 属する症例の症状について，それらの一定期間前後 での変化を考察し，またこの症例を筆者らが考案し た論理演算式に当てはめた結果と審査会の実際の判 断とを比較することによって審査会の判断を評価し たが，大きな社会問題となっている水俣病の認定問 題に対して，認定作業をできるだけ客観的に評価し なおすという本研究の方法は社会医学的な観点から も有用であり意義があると考える。

現行の認定基準が適切ではないという指摘は以前 からあるが, 本研究は現行の判断基準自体が妥当な ものであるか否かについて触れるものではない。今 後疫学的な手法を用いて再検討されるべきである。 しかし，本研究の結果により認定審査会において判 断基準自体が適切にあるいは一貫して運用されてい なかった可能性があることが明瞭に示された。

\section{結 論}

1981年 4 月以前に熊本大学医学部の精神神経科教 室が診察し，1975年12月から1981年 4 月までの認定 審査会で審査を受けた患者（3,870例）について， 1975 年 12 月から 1981 年 4 月までの審査会の判断と 1981年 5 月から 1992年 7 月までの認定審査会の判断 の結果と，現行の判断基準を筆者らが独自に再構成 し本症例に当てはめて得られた結果とを比較するこ とによって，審査会の判断を評価した結果以下の知 見を得た。

1) 本症例に関する1981年 5 月から 1997年 9 月まで の審査会による認定は298例でありそれ以前の認定

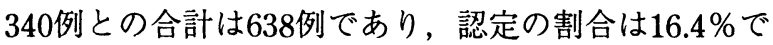


あった。

2) 認定審査会においては現行の判断基準を満たさ ない症例であっても判断基準とは別の考えによって 認定された例がありえたことを認めた。

3 ） 1975年12月から1981年 4 月までの認定群と 1981 年 5 月から 1992 年 7 月までの認定群との比較から認 定審査会では判断基準の適用の一貫性が保たれてい なかったことが明らかにされた。

4 ）認定作業は「専門医の豊富な経験と高度の学識」 によってなされるはずであるが，実際は一貫性に乏 しい上に，多くのばらつきがあることが明らかにさ れた。認定作業は実際の判断基準を公開し，それに 基づいて，公平になされるべきであろう。

\section{謝 辞}

本論文をまとめるにあたり指導していただいた岡 山大学医学部衛生学教室青山英康先生, 三野善央先 生, 津田敏秀先生, 松岡宏明先生に深謝いたします。

\section{文 献}

1) 公害の影響による疾病の指定に関する検討委員 会. 有機水銀関係資料. 環境庁 1972 .

2) 喜多村正次, 宮田仲蔵, 富田 實, 他. 水俣地方 に発生した原因不明の中枢神経系疾患に関する疫 学調査成績. 熊本医学会誌 $1957 ; 31: 1-9$.

3) 喜多村正次, 宮田仲蔵, 富田 實, 他. 水俣地方 に発生した原因不明の中枢神経系疾患に関する疫 学調査成績補遺. 熊本医学会誌 $1957 ; 31: 238-42$.

4) 喜多村正次, 宮田仲蔵, 富田 實, 他. 水俣地方 に発生した原因不明の中枢神経系疾患に関する疫 学調査成績補遺 (その 2 ). 熊本医学会誌 1957 ; $33: 569-71$.

5) 忽那将愛 (編集代表). 水俣病-有機水銀中毒に関す る研究-. 熊本大学医学部水俣病研究班 1966 .

6) 野村 茂, 松下敏夫, 二塚 信, 他. 水俣病の推 移とその疫学的研究-水俣,御所浦地区住民の健康 調査成績(その 1), 10年後の水俣病に関する疫学 的,臨床医学的ならびに病理学的研究. 熊本大学医 学部 10 年後の水俣病研究班, 報告書 (第 1 年 度) $1972: 6-36$.

7) 野村 茂, 松下敏夫, 二塚 信, 他. 水俣病の推 移とその疫学的研究(その 2$), 10$ 年後の水俣病に 関する疫学的, 臨床医学的ならびに病理学的研究. 熊本大学医学部 10 年後の水俣病研究班, 報告書 (第 2 年度) $1973: 17-47$.

8) 立津政順, 津田一民, 原田正純, 他. 水俣病の精 神神経学的研究, 熊本大学医学部 10 年後の水俣病 研究班, 10年後の水俣病に関する疫学的臨床医学 的ならびに病理学的研究, 第 1 年度1972:41-65.
9) 立津政順，津田一民，原田正純，他．不知火海沿 岸住民の健康に及ぼす有機水銀污染魚介類摂取の 影響に関する研究, 熊本大学医学部10年後の水俣 病研究班, 10年後の水俣病に関する疫学的臨床医 学的ならびに病理学的研究, 第 2 年度 $1973: 48$ 87.

10) 松下敏夫, 二塚 信, 有松徳樹, 他. 水俣病の推 移とその疫学的研究(その 1 ) 水俣, 御所浦地区住 民の健康調査成績. 熊本医学会誌 $1972 ； 46 ： 641$ 60.

11) 松下敏夫, 二塚 信, 照屋博行, 他. 水俣病の推 移とその疫学的研究(その 2 )地域保健指標からみ た環境污染の影響. 熊本医学会誌 $1974 ； 48 ： 124$ 32.

12) 松下敏夫, 二塚 信, 有松徳樹, 他. 水俣病の推 移とその疫学的研究(その 3 )水俣病の住民検診に 関する考察. 熊本医学会誌 $1974 ; 48: 133-45$.

13) 藤野 糺. ある島における住民の有機水銀污染の 影響に関する臨床疫学的研究, 第 1 報 污染地区 住民の一斉検診。熊本医学会誌別刷1977；51：2262.

14) 藤野 糺. ある島における住民の有機水銀污染の 影響に関する臨床疫学的研究, 第 2 報 非污染地 区住民の一斉検診. 熊本医学会誌別刷 $1977 ; 51$ ： 90-147.

15) 原田正純. 16年後の水俣病の臨床的 - 疫学的研究. 神経進歩 $1972 ； 16: 870-80$.

16) 武内忠男, 衛藤光明. 人の慢性発症水俣病（慢性 メチル水銀中毒症）の病理発生，とくに原因発生 について．神経進歩1974；18：845-60.

17) 内野 誠, 荒木淑郎. 最近の水俣病-認定患者 100 例の神経症候の分析を中心に-。臨床神経学 1984 ; $24: 235-39$.

18）内野 誠, 荒木淑郎. 慢性水俣病診断の問題点-神 経症候並びに患者老齢化に伴う各種合併症の実態 を中心に。臨床神経学1987；27：204-10.

19）荒木淑郎. 水俣病. 現代医療1988；20：1923-27.

20)原田正純。水俣が映す世界。日本評論社, 東京 1989.

21) 藤野 糺, 板井八重子. 水俣病の現在の医学的問 題点. 公害研究 $1982 ; 11: 2-12$.

22) 池田貞雄, 宮井正彌. 医学のなかの統計学 IV-熊 本水俣病の統計 (2)-。情報研究(創価大学情報科 学研究所) $1988 ; 4: 1-6$.

23) 宮井正彌. 熊本水俣病における認定審査会の判断 についての評価。日衛誌 $1997 ; 51 ： 711-21$.

24) 原田正純. 慢性水俣病. 実教出版, 東京1994： 138.

25)熊本県発表患者処分状況，水俣. 水俣病を告発す る会 $1995 ; 248: 4$.

26) 樺島啓吉, 南 龍一, 藤野 糺, 原田正純. 慢 
日衛誌（Jpn. J. Hyg.）第54巻 第 2 号 1999年 7 月

性水俣病における発作性症状と脳波所見。臨床脳 波1977；19：722-36.

27) 環境庁企画調整局環境保健部長. 後天性水俣病の 判断条件について(通知)。ジュリスト $1986 ； 866$ ： 73.

28) 原田正純. 不知火海有機水銀污染の医学的追及, 色川大吉編。水俣の啓示(上). 筑摩書房, 東京
$1983: 325-88$.

29) 白川健一, 広田紘一, 神林敬一郎, 椿 忠雄. 新 潟水俣病の疫学と臨床. 神経進歩 $1972 ； 16 ： 881$ 91.

30) 白川健一, 神田武政. 水俣病診断のための新しい 試み. 科学 $1978 ； 48 ： 559-67$. 